\title{
The Mental Health and Wellbeing of EU Citizens in the UK: A Systematic Review of the Qualitative Literature
}

\author{
Piotr Teodorowski ${ }^{ \pm}$, Ruth Woods ${ }^{\ddagger}$, and Catriona Kennedy ${ }^{\mu}$
}

\begin{abstract}
Moving to a new country impacts on migrants' mental health and well-being. There are over 3.6 million European Union citizens living in the United Kingdom. We conducted a systematic review of the qualitative literature to explore what is known about their mental health and well-being at the post-migration stage in pre-Brexit period. We searched five databases from 1st January 2009 to 19th February 2019; Web of Science, MEDLINE, CINAHL, SocIndex and Scopus for studies. Ten papers reporting nine studies were included in this review. Two themes were constructed; a narrative of adjustment and of employment realities. The former focuses on the process of settling in and the role of social connectedness. The latter concerns employment realities with included studies exploring the financial position and employment experiences of migrants. Findings indicate that we still know relatively little about the range of post-migration experiences among EU citizens and their implications for mental health.
\end{abstract}

Keywords: migration; mental health; EU; United Kingdom; integration.

\section{Introduction}

The relationship between migration and mental health is widely recognised. (Bhugra, 2004; Close et al., 2016; Kirmayer et al., 2011; Pumariega et al., 2005). Understanding it is vital as good mental health is a positive integration factor (Ndofor-Tah et al., 2019) and unsupported migrants may struggle to settle into a new environment (Pumariega et al., 2005). We use the World Health Organisation (2014) definition of mental health as: "...a state of well-being in which every individual realises his or her own potential, can cope with the normal stresses of life, can work productively and fruitfully, and is able to make a contribution to her or his community." Factors influencing migrants' well-being derive from pre-, during and post-migration stages with the last stage having a profound impact on migrants' long-term mental health (Kirmayer et al., 2011; Pumariega et al., 2005). These include uncertainty around legal rights and access to services, low socio-economic status, loss of social links and connections with friends and family (including future reunions), and social exclusion (Kirmayer et al., 2011; Wiking et al., 2004).

\footnotetext{
${ }^{ \pm}$Piotr Teodorowski, School of Nursing and Midwifery, Robert Gordon University, Aberdeen, United Kingdom. E-mail: Teodorowski.piotr@gmail.com.

$¥$ Ruth Woods, School of Applied Social Studies, Robert Gordon University, Aberdeen, United Kingdom.

E-mail: r.woods3@rgu.ac.uk.

${ }^{\mu}$ Catriona Kennedy, School of Nursing and Midwifery, Robert Gordon University, Aberdeen, United Kingdom.

E-mail: c.m.kennedy1@rgu.ac.uk.
} 


\section{The Mental Health and Wellbeing of EU Citizens in the UK}

Settling in a new country can be stressful and impact on migrants' mental health and wellbeing. To integrate into a new society, migrants may need to learn a new language, build links with the local community, deal with different cultural, societal and gender roles, shift their cultural identity and find employment. When migrants struggle with these adaptations, they experience acculturative stress, which can lead to increased anxiety and depression (Berry et al., 2011; Schwartz et al., 2010). Unfair treatment, prejudice and discrimination of migrants by the host population is associated with their deteriorating mental health over the long-term (Bhui et al., 2005; Schmitt et al., 2014; Wallace et al., 2016). Those who have a strong relationship with their ethnic and cultural identity are more vulnerable to a higher level of acculturative stress, especially when feeling alienated from society (Amer \& Hovey, 2007; Hong, 2019). These factors can lead to social isolation, especially when someone struggles to establish new social links because of language or cultural barriers. Family relationships are an important source of support for those who face acculturation barriers (Ibañez et al., 2015).

The relationship between migration and mental health is multidimensional and complex. Social context which includes, but is not limited to, their legal status, language fluency and the cultural similarities between the host country and that of origin affect the experiences of migrants (Bhugra \& Jones, 2001). Thus, research needs to take in to account the specific context of migration in order to advise health and social care professionals and those who work in the third sector and support organisations on how to support the people, families and communities they work with.

Migrants normally move to a new country to improve their life, economic or health situation and this may lead to higher stress levels if their expectations are not met. Levels of satisfaction depend on both economic and non-economic (e.g. pro-migrant environment) aspects of migration (Hendriks \& Bartram, 2016). However, when compared to their home country experiences and opportunities, there can also be positive effects of migration on mental health and well-being (Lulle \& King, 2016; Stillman et al., 2009; Stillman et al., 2015).

This paper reviews evidence about the experience of the European Union (EU) citizens who moved to the United Kingdom (UK). Our focus on the UK was determined by the sizeable and diverse migrant population which exists and the resulting challenges for policymakers and health and social care and third sector professionals (Phillimore, 2011), Over 3,6 million EU citizens reside in the UK (Office for National Statistics, 2019b). The largest influx of EU migrants happened post2004 when ten new states joined the EU. EU citizens who migrate to the UK do so most commonly for work (Office for National Statistics, 2019a).

The range of post-migration factors influencing mental health and well-being in the UK is relatively unexplored. Non-white migrants in the UK may have better mental health and well-being than the host population (Dhadda \& Greene, 2018). However, to our knowledge, there is no review exploring health and well-being across EU citizens. We also have not found any systematic reviews exploring the mental health and well-being of EU citizens in the UK as a heterogeneous group. Previous reviews have explored single European nationalities (Maciagowska \& Hanley, 2018). This focus on specific groups of EU nationals is important, but we suggest that it should be complemented by a broader understanding of the mental health of EU citizens as a whole in the UK. Our intention is not to suggest that experiences across this heterogenous group can be generalised but rather to review the evidence across this population in order to understand the issues they face. Since Brexit, EU citizens have frequently been considered as a homogenous group. However, without fully understanding pre-Brexit period we can't fully understand the mental health of EU 
citizens in the UK following Brexit. We suggest, then, that it would be useful to capture their preBrexit experiences. This systematic review aims to fill this gap and inform evidence-based practice regarding the challenges EU citizens in the UK faced around mental health and well-being prior to Brexit. The is timely as Brexit, along with the associated political discourse, has added another layer of stressors for EU citizens (Teodorowski et al., 2019a).

\section{Methods}

The approach used in this review needed to be suited to the exploration of a phenomenon (lived experiences) in depth. Given the focus of our questions on experiences, we judged the available evidence was likely to be drawn from primary qualitative empirical studies. We, therefore, used a systematic approach adapted from methodologies proposed by Whittemore and Knafl (2005), the Cochrane Collaboration (2019) and the PRISMA guidelines (Moher et al., 2009).

A rigorous process was followed with each step involving at least two reviewers. This was to increase robustness and enhance the confidence with which the reader can consider these findings. Identifying the review aims and questions, constructing a search strategy; study selection; quality appraisal and data extraction; summarising, synthesising and reporting of results were the key stages. A PROSPERO protocol was developed, and this guided the conduct of the review (Teodorowski et al., 2019b). This paper does not contain any studies with human participants performed by any of the authors. The review was discussed with the Convenor of the School of Nursing and Midwifery Ethics Review Panel at Robert Gordon University, who confirmed it would not require ethical approval.

\section{Review aims and questions}

A critical review of empirical qualitative literature using a systematic approach has been conducted to address a key aim: To identify what evidence there is around the lived experiences and impact on the mental health and well-being of EU citizens who migrate to the UK.

Three review questions were posed:

- How does migration impact on EU citizens' mental health and well-being?

- How do EU citizens cope with mental health and well-being issues?

- Are there any organisational issues which affect their experiences of migrating to the UK from other EU countries?

\section{Search strategy}

A search strategy was developed and refined in consultation with an information specialist. Five databases were searched from $1^{\text {st }}$ January 2009 to $19^{\text {th }}$ February 2019; Web of Science, MEDLINE, CINAHL, SocIndex and Scopus. MesH terms and keywords were used with Boolean operators. Table 1 provides an example of the Medline search.

We searched for qualitative empirical and interpretive studies that presented findings on the lived experiences of EU citizens in the UK. The World Health Organisation (2014) definition of mental health informed our review at each stage of decision making. Clear inclusion criteria were set for studies that; 
- Explored the experiences of adult (age 18 and above) EU citizens who had migrated to the UK;

- were published from 1st January 2009 in English.

Table 1. Sample Medline search

"mental health" or well-being or stress or distress or depression

AND EU or European or Polish or Poland or Pole* or Irish or Ireland or French or France or German or Germany or Italy or Italian or Spain or Spanish or Greece or Greek or Romania or Romanian or Hungar* or Bulgar* or Lithuan* or Latvia* or Latvian* or Lithuania* or Portug* or Austria or Austrian* or Belgium or Belgian* or Croatia* or Cyprus or Cypriot* or Czech* or Den* or Estonia* or Finland or Finnish or Ireland or Irish or Luxembourg* or Malt* or Netherlands or Dutch or Portug* or Slov* or Sloveni* or Swed*

AND migrant* or migration or immigrant* or immigration or "ethnic minorit*"

AND UK or "United Kingdom" or Britain or Scotland or England or Wales or "Northern Ireland" or London

\section{Study selection}

Following the database search, all titles were screened by the lead author. The other two reviewers each screened half of the titles. The review team then met to agree on the titles which should be reviewed at the stage of the abstract and then subsequently the full paper. Two reviewers were involved in decision making of titles, abstracts and full papers with the third team member arbitrating in any disagreements. We are, therefore confident that our process for selecting studies for inclusion was robust.

Once the included papers were identified the next stage was to move to quality appraisal and data extraction. This step also involved all three reviewers with the lead author extracting and appraising all included papers and the two other reviewers again working with half. We developed a data extraction tool which contained two screening questions;

- Does the paper provide evidence around mental health and well-being of EU citizens in the $\mathrm{UK}$ ?

- Does the paper reflect the WHO definition of mental health and well-being?

Reasons for exclusion at the full-text stage were documented in PRISMA (see Figure 1). The next stage was to extract the study details, study aims and methods and ethical considerations. We extracted the authors' findings and mapped these to our three research questions and included any other relevant information.

All included studies were quality appraised using the CASP (2018) qualitative checklist, which has ten criteria against which to appraise qualitative research studies. It does not provide a scoring system per se but using such an approach allows reviewers to notice patterns across the body of evidence. The overall purpose in this review was not to exclude on the basis of quality but rather to allow us to draw some conclusions on the overall quality of the evidence which exists. 


\section{Figure 1. PRISMA}

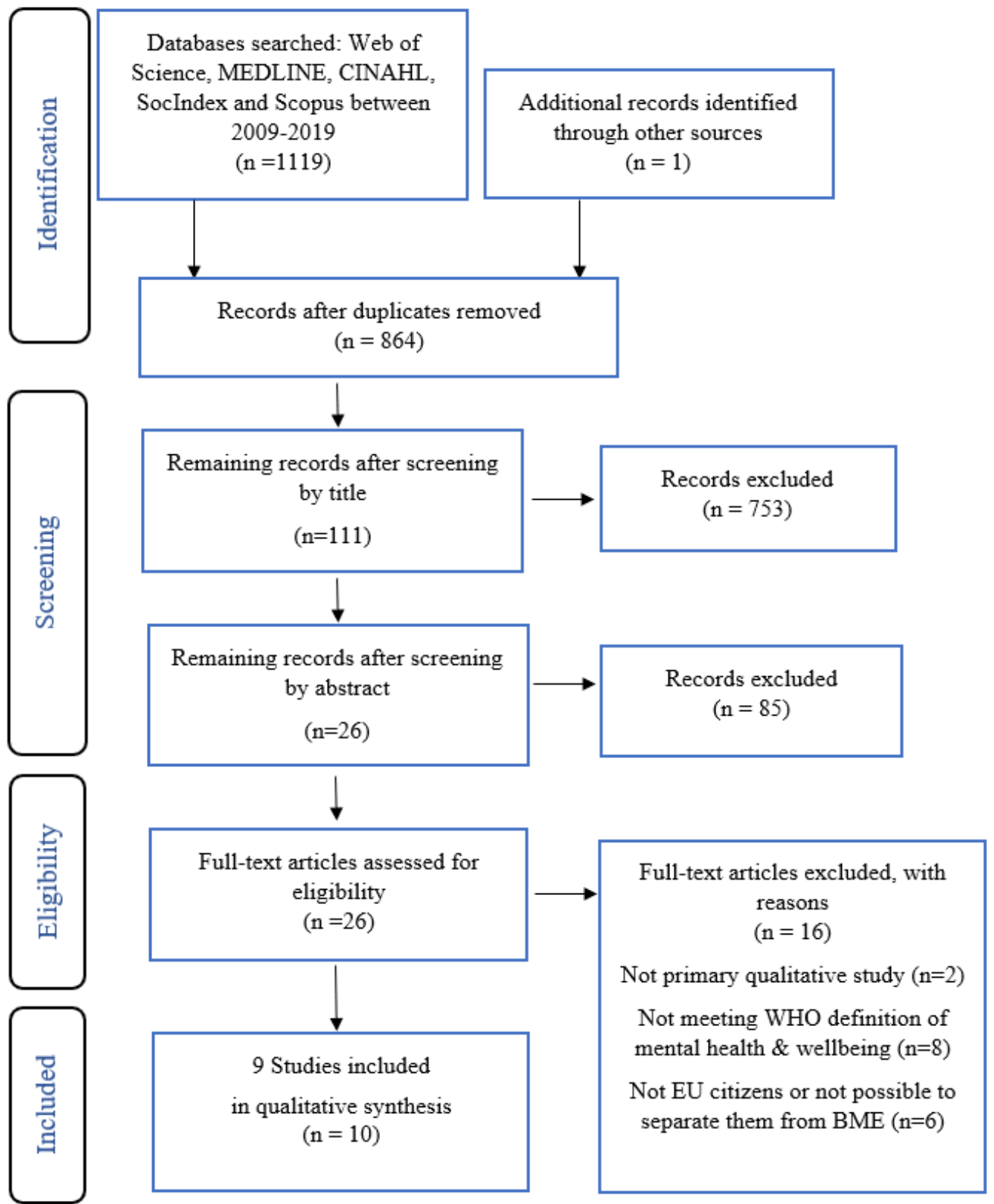

\section{Analysis and synthesis}

Following the process of data extraction, we moved to the analysis and synthesis of the findings. Given that this review extracted qualitative findings, we conducted a thematic analysis using the steps outlined by Braun and Clark (2006). All reviewers were involved in the process of identifying codes and themes and we discussed these at a series of analysis sessions. Themes were 
developed inductively and iteratively and agreed by the reviewers around a narrative of adjustment and employment realities.

To increase the confidence in the findings from this review, we applied the CerQUAL criteria (Lewin et al., 2015). CerQUAL is an approach to grading the overall quality of the evidence which underpins key findings. We judged that methodological issues, relevance, coherence and adequacy of the included studies impacted on our overall confidence in the findings linked to the two key themes. Using CerQUAL we judged the overall confidence we could have in these review findings as a medium for the narrative of adjustment and low for employment realities (see Table 3). The findings are now reported below.

Table 2. Summary of findings

\begin{tabular}{|c|c|c|c|c|c|c|}
\hline Name & Title & Journal & $\begin{array}{l}\text { Site (when } \\
\text { specified) }\end{array}$ & Methods & Population & Key messages \\
\hline $\begin{array}{l}\text { Brown, L. \& } \\
\text { Paszkiewicz, } \\
\text { I. } 2017\end{array}$ & $\begin{array}{l}\text { The role of food in } \\
\text { the Polish migrant } \\
\text { adjustment } \\
\text { journey. }\end{array}$ & Appetite & UK & $\begin{array}{l}\text { Interviews } \\
(\mathrm{n}=9)\end{array}$ & Polish & $\begin{array}{l}\text { Polish food is a } \\
\text { crucial and } \\
\text { irreplaceable } \\
\text { element of life } \\
\text { Some peruse a } \\
\text { segregation } \\
\text { acculturation } \\
\text { strategy when it } \\
\text { comes to food }\end{array}$ \\
\hline $\begin{array}{l}\text { Christensen, } \\
\text { K., \& } \\
\text { Manthorpe, } \\
\text { J. } 2016\end{array}$ & $\begin{array}{l}\text { Personalised risk: } \\
\text { new risk } \\
\text { encounters facing } \\
\text { migrant care } \\
\text { workers }\end{array}$ & $\begin{array}{l}\text { Health, Risk } \\
\text { \& Society }\end{array}$ & England & $\begin{array}{l}\text { Interviews } \\
(\mathrm{n}=31)\end{array}$ & $\begin{array}{l}\text { Care workers } \\
\text { coming from } \\
\text { both EU } \\
(\mathrm{n}=13) \text { and } \\
\text { non-EU } \\
\text { countries } \\
(\mathrm{n}=18)\end{array}$ & $\begin{array}{l}\text { Migrant care } \\
\text { workers face risks } \\
\text { and concerns } \\
\text { around insecure, } \\
\text { employment; } \\
\text { emotionalised } \\
\text { relationships; } \\
\text { intimacy and } \\
\text { exploitation. }\end{array}$ \\
\hline $\begin{array}{l}\text { Cieslik, A. } \\
2011\end{array}$ & $\begin{array}{l}\text { Where Do You } \\
\text { Prefer to Work? } \\
\text { How the Work } \\
\text { Environment } \\
\text { Influences Return } \\
\text { Migration } \\
\text { Decisions from the } \\
\text { United Kingdom to } \\
\text { Poland }\end{array}$ & $\begin{array}{l}\text { Journal of } \\
\text { Ethnic and } \\
\text { Migration } \\
\text { Studies }\end{array}$ & London & $\begin{array}{l}\text { Interviews } \\
(\mathrm{N}=60)\end{array}$ & $\begin{array}{l}\text { Skilled } \\
\text { migrants in } \\
\text { London and } \\
\text { returnees to } \\
\text { Poland } \\
\text { (approximately } \\
\text { half in each } \\
\text { location) }\end{array}$ & $\begin{array}{l}\text { Workplace stress } \\
\text { has different } \\
\text { functions in Polish } \\
\text { and UK contexts. } \\
\text { Positive work } \\
\text { experience is a pull } \\
\text { factor for } \\
\text { professionals. }\end{array}$ \\
\hline $\begin{array}{l}\text { Condon, L., } \\
\text { J. \& } \\
\text { McClean, S. } \\
2016\end{array}$ & $\begin{array}{l}\text { Maintaining pre- } \\
\text { school children's } \\
\text { health and well- } \\
\text { being in the UK: a } \\
\text { qualitative study of } \\
\text { the views of } \\
\text { migrant parents }\end{array}$ & $\begin{array}{l}\text { Journal of } \\
\text { Public } \\
\text { Health }\end{array}$ & UK & $\begin{array}{l}\text { Focus } \\
\text { Groups } \\
(\mathrm{n}=5)\end{array}$ & $\begin{array}{l}\text { Parents of pre- } \\
\text { school children } \\
\text { from Poland } \\
(\mathrm{n}=6), \\
\text { Romania } \\
\text { (including } \\
\text { Roma)(n=13), } \\
\text { Somalia ( } \mathrm{n}=5) \\
\text { and Pakistan } \\
\text { (p4) living in } \\
\text { socio- } \\
\text { economic } \\
\text { deprivation. }\end{array}$ & $\begin{array}{l}\text { Parents face } \\
\text { multiple and } \\
\text { multidirectional } \\
\text { barriers to child } \\
\text { health around } \\
\text { socio-economic } \\
\text { well-being and } \\
\text { healthy life choices }\end{array}$ \\
\hline
\end{tabular}


Table 2. Summary of findings (continued)

\begin{tabular}{|c|c|c|c|c|c|c|}
\hline Name & Title & Journal & $\begin{array}{l}\text { Site (when } \\
\text { specified) }\end{array}$ & Methods & Population & Key messages \\
\hline $\begin{array}{l}\text { Farr, J., et all } \\
2018\end{array}$ & $\begin{array}{l}\text { "It's My } \\
\text { Language, My } \\
\text { Culture, and it's } \\
\text { Personal!” Migrant } \\
\text { Mothers' } \\
\text { Experience of } \\
\text { Language Use and } \\
\text { Identity Change in } \\
\text { Their Relationship } \\
\text { With Their } \\
\text { Children: An } \\
\text { Interpretative } \\
\text { Phenomenological } \\
\text { Analysis }\end{array}$ & $\begin{array}{l}\text { Journal of } \\
\text { Family } \\
\text { Issues }\end{array}$ & UK & $\begin{array}{l}\text { Interviews } \\
(\mathrm{n}=4)\end{array}$ & $\begin{array}{l}\text { Spanish } \\
\text { women, aged } \\
35-42 \text { who had } \\
\text { grown up in } \\
\text { Spain and } \\
\text { moved to the } \\
\text { UK as a young } \\
\text { adult. Educated } \\
\text { to degree or } \\
\text { postgraduate } \\
\text { level and } \\
\text { worked in } \\
\text { skilled } \\
\text { professions. }\end{array}$ & $\begin{array}{l}\text { Use of mother } \\
\text { tongue is linked } \\
\text { to perceptions of } \\
\text { self-identity and } \\
\text { belonging. } \\
\text { Resulting in } \\
\text { conflict for the } \\
\text { individuals and } \\
\text { impact on } \\
\text { psychological } \\
\text { well-being. }\end{array}$ \\
\hline $\begin{array}{l}\text { Lee- } \\
\text { Treweek, G. } \\
2013\end{array}$ & $\begin{array}{l}\text { 'Sometimes I just } \\
\text { wish I never hear } \\
\text { of this term } \\
\text { bilingual worker': } \\
\text { difficult clients, } \\
\text { emotion work and } \\
\text { interpreting with } \\
\text { migrants. }\end{array}$ & $\begin{array}{l}\text { International } \\
\text { Journal } \\
\text { Work, } \\
\text { Organisation } \\
\text { and Emotion }\end{array}$ & $\begin{array}{l}\text { England } \\
\text { (Staffordshire, } \\
\text { Cheshire, } \\
\text { Derbyshire } \\
\text { and Greater } \\
\text { Manchester). }\end{array}$ & $\begin{array}{l}\text { Interviews } \\
(\mathrm{n}=16)\end{array}$ & $\begin{array}{l}\text { Polish bilingual } \\
\text { workers, } \\
\text { female }(\mathrm{n}=11) \\
\text { and male } \\
(\mathrm{n}=5) \text {, working } \\
\text { in local } \\
\text { authority or } \\
\text { health and } \\
\text { social care } \\
\text { settings. }\end{array}$ & $\begin{array}{l}\text { Clients, who } \\
\text { lived in the same } \\
\text { neighbourhood } \\
\text { got in touch with } \\
\text { bilingual workers } \\
\text { causing stress } \\
\text { and breaching } \\
\text { private life. } \\
\text { Leading to } \\
\text { negative } \\
\text { emotional } \\
\text { consequences as } \\
\text { workers } \\
\text { struggled to keep } \\
\text { work-life } \\
\text { balance. }\end{array}$ \\
\hline $\begin{array}{l}\text { Lulle A, \& } \\
\text { King, R. } \\
2016\end{array}$ & $\begin{array}{l}\text { Ageing well: the } \\
\text { time-space of } \\
\text { possibility for } \\
\text { older female } \\
\text { Latvian migrants } \\
\text { in the UK }\end{array}$ & $\begin{array}{l}\text { Social \& } \\
\text { Cultural } \\
\text { Geography }\end{array}$ & $\begin{array}{l}\text { London, } \\
\text { Boston } \\
\text { (Lincolnshire) } \\
\text { and the } \\
\text { Channel } \\
\text { Island } \\
\text { Guernsey }\end{array}$ & $\begin{array}{l}\text { Interviews } \\
(n=37)\end{array}$ & $\begin{array}{l}\text { Older and } \\
\text { soon-to-be- } \\
\text { ageing } \\
\text { Latvians. }\end{array}$ & $\begin{array}{l}\text { Older, working } \\
\text { migrants received } \\
\text { both material and } \\
\text { psychosocial } \\
\text { resources to } \\
\text { enhance } \\
\text { opportunities for } \\
\text { 'ageing. } \\
\text { Pressures to } \\
\text { return home by } \\
\text { family members } \\
\text { were mostly } \\
\text { resisted- the } \\
\text { independence } \\
\text { and freedom (e.g. } \\
\text { new } \\
\text { relationships) } \\
\text { afforded in the } \\
\text { UK was valued } \\
\text { by participants. }\end{array}$ \\
\hline
\end{tabular}


Table 2. Summary of findings (continued)

\begin{tabular}{|c|c|c|c|c|c|c|}
\hline Name & Title & Journal & $\begin{array}{l}\text { Site (when } \\
\text { specified) }\end{array}$ & Methods & Population & Key messages \\
\hline $\begin{array}{l}\text { O’Brien \& } \\
\text { Tribe } 2014\end{array}$ & $\begin{array}{l}\text { Exploring Polish } \\
\text { migrants' } \\
\text { adaptation to life } \\
\text { in the UK: an } \\
\text { interpretative } \\
\text { phenomenological } \\
\text { analysis }\end{array}$ & $\begin{array}{l}\text { International } \\
\text { Journal of } \\
\text { Culture and } \\
\text { Mental } \\
\text { health }\end{array}$ & London & $\begin{array}{l}\text { Interviews } \\
(\mathrm{n}=8)\end{array}$ & $\begin{array}{l}\text { Polish. } \\
\text { Seven } \\
\text { female and } \\
\text { one male. }\end{array}$ & $\begin{array}{l}\text { The openness and } \\
\text { tolerance that participants } \\
\text { perceive in the UK in } \\
\text { contrast to Poland may } \\
\text { facilitate acculturation } \\
\text { and integration. }\end{array}$ \\
\hline $\begin{array}{l}\text { Weishaar } \\
2008\end{array}$ & $\begin{array}{l}\text { Consequences of } \\
\text { international } \\
\text { migration: A } \\
\text { qualitative study } \\
\text { on stress among } \\
\text { Polish migrant } \\
\text { workers in } \\
\text { Scotland } \\
\text { "You have to be } \\
\text { flexible"- Coping } \\
\text { among Polish } \\
\text { migrant workers } \\
\text { in Scotland. }\end{array}$ & $\begin{array}{l}\text { Public } \\
\text { Health } \\
\text { Health \& } \\
\text { Place }\end{array}$ & $\begin{array}{l}\text { Scotland } \\
\text { (Edinburgh) }\end{array}$ & $\begin{array}{l}\text { Interviews } \\
(\mathrm{n}=8) \text { and } \\
\text { focus } \\
\text { groups } \\
(\mathrm{n}=2) .\end{array}$ & $\begin{array}{l}\text { Polish. } \\
\text { Nine } \\
\text { female and } \\
\text { six male. }\end{array}$ & $\begin{array}{l}\text { Migration is } \\
\text { multidirectional } \\
\text { (psychological, social and } \\
\text { physical) with many } \\
\text { drivers which impact on } \\
\text { health and well-being. } \\
\text { Migrants are vulnerable to } \\
\text { mental health issues due } \\
\text { to stress linked to } \\
\text { migration. } \\
\text { No coping strategy is } \\
\text { superior, and these are } \\
\text { interdependent on formal } \\
\text { (especially. workplace) } \\
\text { and informal support and } \\
\text { influenced by context. } \\
\text { An appraisal is an } \\
\text { important feature but } \\
\text { differs between } \\
\text { individuals; one situation } \\
\text { can be seen as stressful } \\
\text { and threating and be } \\
\text { manageable by another }\end{array}$ \\
\hline
\end{tabular}

\section{Findings}

Database and manual searches identified 1120 records. After removing duplicates, 864 papers were screened by title, abstract $(n=111)$ and full text $(n=26)$. Thus, nine studies reported in ten papers were included in the qualitative synthesis. Two descriptive themes were constructed from the analysis process. The first, narrative of adjustment, focuses on the process of settling in the UK and the role of social connectedness (Brown \& Paszkiewicz, 2017; Christensen \& Manthorpe, 2016; Cieslik, 2011; Condon \& McClean, 2017; Farr et al., 2018; Lee-Treweek, 2013; Lulle \& King, 2016; O'Brien \& Tribe, 2014; Weishaar, 2008, 2010). The second theme concerns employment realities as the majority of studies explored the financial position and employment experiences of EU citizens (Brown \& Paszkiewicz, 2017; Christensen \& Manthorpe, 2016; Cieslik, 2011; Condon \& McClean, 2017; Lee-Treweek, 2013; Lulle \& King, 2016; O’Brien \& Tribe, 2014; Weishaar, 2008, 2010). The most researched EU citizen group was Polish (six studies). Two papers explored both EU and non-EU migration to the UK. Only data that had clearly come from EU participants was included. The studies were conducted in England $(n=5)$, Scotland $(n=2)$, Guernsey $(n=1)$, and three studies did not specify the geographical location. One study design was mixed-method (Cieslik, 2011) and the qualitative data were extracted. 


\section{Narrative of Adjustment}

Settling in the UK was a personal journey for many EU citizens utilising various strategies to adjust to this new environment. This theme shows how hey adjusted, established new relationships and connections in the community.

\section{Pathways of adjustment}

Several studies identified that EU citizens adjusted to their new life in the UK (Brown \& Paszkiewicz, 2017; Condon \& McClean, 2017; Farr et al., 2018; Lulle \& King, 2016; Weishaar, $2008,2010)$. However the pathway to adjustment took time, was individualised and not necessarily linear or successful (Brown \& Paszkiewicz, 2017; Condon \& McClean, 2017; Weishaar, 2010) On moving to the UK some migrants found it hard to cope with the changes. They faced a range of issues such as poor weather, which made them feel depressed (Brown \& Paszkiewicz, 2017). For some, their diet changed; for some, initial financial struggles led to an unhealthy diet and weight gain (Brown \& Paszkiewicz, 2017; Weishaar, 2008). They did not know the 'rules of the game' as they were unfamiliar with British cultural norms and institutions (Weishaar, 2008). Many EU citizens adjusted to these changes over time and wanted to remain in the UK (Lulle \& King, 2016). However, some found it hard to adjust, and for others, life events, such as becoming a parent or events at home, could cause feelings of adjustment to life in the UK to regress. Becoming a parent presented new challenges and additional stressors such as difficulties communicating with offspring in their mother tongue (Farr et al., 2018).

Relationships with home countries influenced pathways of adjustment. EU citizens missed their national foods. Poles would turn to Polish and Eastern Europeans shops to obtain more traditional products (Brown \& Paszkiewicz, 2017). Before international shops were available Polish people would bring food from Poland to the UK. National food was comforting to migrants and helped to maintain nostalgic memories. EU citizens sometimes faced pressures from their families to return to their home countries. This was particularly difficult for those who perceived their overall quality of life in the UK to be better than their home country (Lulle \& King, 2016). When children were born in the UK, parents who had grown up elsewhere were keen for them to be connected with their countries of origin. Parents were distressed when they spoke in their mother tongue to children but received an answer in English (Farr et al., 2018). Some expressed the desire to share their culture and heritage and to keep their language alive in the next generation (Farr et al., 2018).

\section{Social connectedness}

EU citizens' links with friends, family and ways of communicating changed when they moved to the UK (Brown \& Paszkiewicz, 2017; Christensen \& Manthorpe, 2016; Farr et al., 2018; Lulle \& King, 2016; O’Brien \& Tribe, 2014; Weishaar, 2008, 2010). Many left their friends and family behind in the country of origin. Social isolation made them feel lonely (Brown \& Paszkiewicz, 2017; Christensen \& Manthorpe, 2016; O'Brien \& Tribe, 2014; Weishaar, 2008, 2010) and lacking the support of social networks to cope with daily life, such as family-based childcare for working parents. The lack of family support was especially felt when the cost of childcare was high, and incomes were low. Communication included both English and EU citizens' mother tongue. Fluency in English was needed in everyday situations to integrate into British society, for example, getting a good, well-paid job and making new friends outside of their language group (Brown \& Paszkiewicz, 2017; Lulle \& King, 2016; Weishaar, 2008). Some who struggled linguistically 
reported lower self-esteem and felt angry and isolated (Brown \& Paszkiewicz, 2017). Speaking in one's mother tongue with family members, especially children in mixed ethnic marriages, was important to foster intimacy in the parent-child relationship (Farr et al., 2018). Migrant parents often compared their experiences of growing up to that of their children. Some who had lived in the UK for a long time found that they started to speak both their mother tongue and English with an accent. This contributed to feelings of belonging neither in the UK nor their home country (Farr et al., 2018).

\section{Strategies for adjustment}

Five studies discussed the strategies that EU citizens used to improve their adjustment journey (Brown \& Paszkiewicz, 2017; Lee-Treweek, 2013; Lulle \& King, 2016; O’Brien \& Tribe, 2014; Weishaar, 2010). EU citizens could better cope with stress when they could keep their work and life in balance and had time for hobbies and passions (Lee-Treweek, 2013; Lulle \& King, 2016). Participants used a range of coping strategies to adjust to life in the UK. Having friends or family in the UK was helpful as a support network and feeling welcome in the UK helped EU citizens build links with the local community and thus to integrate more easily (Brown \& Paszkiewicz, 2017; O'Brien \& Tribe, 2014; Weishaar, 2010). These factors helped EU citizens to think about their future in the UK in positive terms, and consequently, they were more able to adopt a can-do approach to coping. Some EU citizens who struggled to cope with their adjustment turned to antidepressants and other substances such as alcohol, tobacco or drugs (Lee-Treweek, 2013). Sources of support were both informal (e.g. church, ethnic minority charities and workplace) and formal (e.g. jobcentre, trade unions and public offices) (Lulle \& King, 2016; Weishaar, 2010). Some of the resources were available online. Access to interpreters and translated materials were viewed as beneficial to assist those whose English was limited (Weishaar, 2010).

\section{Employment realities}

As many EU citizens came to the UK to work, employment was a significant part of their lives and thus, the majority of studies focus on it. This theme showed that their financial situation, employment opportunities and working conditions were crucial in the adjustment experience.

\section{Financial position}

A secure financial position for EU migrants was a key component of successful adjustment (Brown \& Paszkiewicz, 2017; Christensen \& Manthorpe, 2016; Condon \& McClean, 2017; LeeTreweek, 2013; Weishaar, 2008). On arrival to the UK, some newcomers struggled to secure employment, and if they did not have access to social support, managing finances could be challenging (Weishaar, 2008). Consequently, they could experience poor working conditions, unsociable hours, low salaries or were underpaid for overtime working especially when facing a language barrier (Brown \& Paszkiewicz, 2017; Christensen \& Manthorpe, 2016; Condon \& McClean, 2017; Weishaar, 2008). Temporary contracts resulted in job insecurity, inadequate training and no sickness or holiday pay (Weishaar, 2008). This impacted on their standard of living and could affect their ability to buy food and cook traditional meals at home (Brown \& Paszkiewicz, 2017). Securing a good and well-paid job was a crucial factor in convincing EU citizens to remain long-term in the UK (Cieslik, 2011). 


\section{Employment opportunities}

Moving to the UK offered EU citizens new life opportunities through employment (Cieslik, 2011; Condon \& McClean, 2017; Lulle \& King, 2016; O'Brien \& Tribe, 2014; Weishaar, 2008). Newcomers with a higher degree and/or specialist experience had a better chance of working within their area of expertise and receiving a good salary. However, finding a job relevant to one's qualification was challenging for those whose knowledge of English was not seen as good enough to do professional jobs. Thus, many EU citizens had to stay in employment for which they were overqualified and received low salaries (Condon \& McClean, 2017; Weishaar, 2008).

When compared to their home countries, some British cultural and societal norms allowed EU citizens to be more active and productive citizens. Being a member of the LGBT community was less taboo in the UK compared with some EU member states and those who lived in the large and multicultural cities benefited from this openness (O’Brien \& Tribe, 2014). In some EU countries, traditional roles prevailed for women. In the UK, some men adopted a more proactive role within the family and childcare (Condon \& McClean, 2017), allowing women to be more active beyond the home and family. Older women could remain in employment and make new relationships which would not be acceptable in their home countries. (Lulle \& King, 2016).

\section{Working conditions}

Working conditions can have a profound influence on the mental health and well-being of EU citizens. (Christensen \& Manthorpe, 2016; Cieslik, 2011; Lee-Treweek, 2013). Newcomers may face additional multifaceted risks in their workplace because of their status and background. Employers may not understand individual migrant needs and the differences among various nationalities and cultural backgrounds. For example, Eastern Europeans were perceived as a homogenous group. Some participants who worked as bilingual workers felt that their employers considered them capable of working only with migrants (Lee-Treweek, 2013).

Additional stressors emerged around work-specific issues. For example, bilingual and care workers who lived in the community reported that some clients approached them outside their working hours. Keeping a work and life balance could be challenging. In the study by Lee-Treweek (2013), participants identified that before starting a job as an interpreter, they did not have any experience of working with distressed and vulnerable individuals. No psychological support was offered for those who interpreted in upsetting circumstances such as death and stillbirth (LeeTreweek, 2013). When interpreting, employees had to stay neutral and were not allowed to advise their clients. However, interpreters were often more knowledgeable around discussed issues than their clients, which led to feelings of helplessness and powerlessness (Lee-Treweek, 2013). In one study care workers were often asked to live with those individuals whom they supported--again making their work-life balance challenging. Lack of social connections caused loneliness (Christensen \& Manthorpe, 2016). Some employers expected intimate and close relations with their carers, which would move beyond reasonable employee-employer rapport. For example, when accompanying their employers on holidays, they were asked to share a room and often bed, so the cost of a trip would be lower (Christensen \& Manthorpe, 2016). Most participants articulating these problems heralded from countries which joined the EU in 2004, but this was not always the case. For instance, some carers interviewed by Christensen and Manthorpe (2016) originated in Portugal and Spain. 


\section{The Mental Health and Wellbeing of EU Citizens in the UK}

The work culture matters. Jobs in the UK were perceived as slightly more stressful than in the home country, but this did not necessarily reduce overall job satisfaction (Cieslik, 2011). For the skilled Polish migrants interviewed by Cieslik (2001), stressful work situations in the UK were related to positive challenges (Cieslik, 2011). British organisations had official policies to reduce stress; for example, a website to manage work-stress run by the public body (Cieslik, 2011). Working conditions were a crucial part in EU citizens' well-being, especially for those who moved for employment.

\section{Discussion}

Despite the large influx of EU migrants into the UK in recent years, relatively little is known about their post-migratory mental health and well-being. Our intention in this review was to begin to fill this gap. We focused on qualitative research because it is best placed to illuminate the lived experiences of EU nationals in the UK. Our first theme, Narratives of Adjustment, encapsulates the experiences of change and adjustment articulated in many of the studies across different EU nationalities. EU citizens identified several changes resulting from migration to the UK, including food, weather and the operation of institutions. Alongside these changes, many also spoke of disruption in social connectedness, resulting from difficulties communicating in English, and/or their physical removal from existing social networks left behind in the country of origin. These are all changes which are commonly experienced by migrants in various settings (Kirmayer et al., 2011; Wiking et al., 2004), and healthcare professionals recognise that language is a barrier to providing services (Sandhu et al., 2013; Teshome Tesfaye \& Day, 2015).

Participants in several studies in this review appeared to present a narrative in which these initial difficulties were gradually overcome, such that life in the UK became progressively easier with time. However, this was not always the case; for some, adjustment remained poor, while for others, it fluctuated in response to life circumstances. This finding supports the argument that acculturation is not stage-like, but rather, varies based on the relationship between the problems a migrant faces, their resources and the opportunities open to them, all of which are subject to change (Berry, 2006). This review identified personal life circumstances such as childbirth as relevant, but we would add that wider societal changes can have a similar effect if they undermine a migrant's integration into the host country. Indeed, recent research found that the Brexit referendum has had precisely this impact on some EU nationals in Britain (Teodorowski et al., 2019a), partly because their connections with local communities were damaged (Guma \& Dafydd Jones, 2019).

Experiences of discrimination can impair mental health among migrant populations (Berry, 2006; Bhui et al., 2005; Wallace et al., 2016). While participants of the studies in this review did mention discrimination and prejudice occasionally, they were not strong themes in this dataset. This may reflect a relatively positive multicultural ideology in the UK over the time period of these studies (Berry, 2006), although discrimination and racism are far from absent in the UK (Brown et al., 2016).

Participants mentioned a range of strategies to cope with acculturation, including both problem-focused (which tackle the cause of stress) and emotion-focused (which attempt to alleviate symptoms of stress) (Folkman \& Lazarus, 1988). Many of the strategies identified in this review were social in nature, with participants seeking support from other people. Social strategies have potential to enable problem-focused and/or emotion-focused coping (Folkman \& Lazarus, 1988). For instance, one might consult an experienced migrant about how to open a bank account (problem- 
based coping) and/or seek sympathy over difficulties in opening a bank account (emotion-based coping). If EU citizens' problem-focused coping is frequently social, then migrants who have not formed local social connections may be particularly vulnerable to stress.

Our second main theme concerned the role of employment in EU citizens' well-being following migration. Our analysis suggested that finances, job opportunities and working conditions all mattered for well-being. EU citizens' experiences in these domains varied hugely. Several studies identified financial precariousness as a critical issue for some EU citizens in the UK. In many cases, this precariousness accompanied the early post-migration period, with financial security improving as migrants found reliable work. However, for some, the sense of being on a financial cliff edge endured, due to low paid and/or capricious employment. When it came to working conditions, again, a wide range of experiences was articulated across the studies. For some, conditions were better in the UK than in the country of origin. Others faced considerable challenges at work, for which they were largely unprepared and untrained.

Experiences of job opportunities were similarly diverse. Some EU citizens struggled to gain employment commensurate with their qualifications - a common problem for migrants (Berry, 2006). In contrast, the UK was experienced by others as providing more and better opportunities than those available to them in their country of origin. This was particularly true for members of groups who had experienced discrimination around employment in their country of origin, based for instance, on gender and/or age. For some of these migrants, the opening up of opportunities was experienced as a new kind of freedom which was compared favourably with their country of origin. Previous research indicates that this expansion of possibilities can create conflict with one's heritage culture (Berry, 2006) but such conflict was not evident in this review.

In this review, employment emerged as an important factor influencing well-being. In some cases, employment appeared to affect mental health via acculturation processes. For instance, securing a job could help migrants to connect with members of the host nation. In other cases, employment appeared to have direct implications for mental health. For instance, we would argue that employers' expectations of intimacy would cause distress to care workers whether or not they were migrants. Nevertheless, this more direct pathway could be exacerbated by one's migrant status; for instance, such a care worker might have less local social support and less knowledge about relevant institutional processes than a member of the host nation. Moreover, migrants may be more likely than host nation members to accept these more difficult job roles.

The dataset reveals a diversity of experience which could not be simply mapped onto the sociopolitical status of the country of origin. Negative employment experiences were voiced not only by members of the 2004 accession countries but also by some members of longer standing EU countries. Likewise, positive employment experiences were voiced by some members of 2004 accession countries. It is important, then, not to make assumptions about employment and wellbeing based on EU citizen's country of origin.

This review has provided insights into certain aspects of EU citizens' experiences in the UK. However, there are some weaknesses. Overall confidence in review findings is medium for the first theme (narratives of adjustment) and low for the second (employment realities) due to the quality of the available evidence. The findings of this review should be considered in that context. The studies addressed a range of research questions and thus may not always have provided data for analysis relevant to our aims. Studies were narrow in focus, including specific occupations and/or 
countries of origin. Therefore, there may be gaps in the review findings. In particular, the nationality most frequently represented was Polish, raising the question of whether the findings hold for citizens of other EU countries. Our focus on qualitative research may have missed some relevant quantitative research on EU citizens' mental health in the UK. Moreover, our finding shows that employment was a major contributor to well-being suggests that there may be additional literature which does not explicitly discuss well-being, and thus was not captured by this review, yet which may contribute to our understanding of this topic.

Table 3. CerQUAL: overall confidence in the findings

\begin{tabular}{|c|c|c|c|c|c|c|}
\hline $\begin{array}{l}\text { Review } \\
\text { Finding }\end{array}$ & $\begin{array}{l}\text { Assessment of } \\
\text { Methodological } \\
\text { Limitations }\end{array}$ & $\begin{array}{l}\text { Assessment } \\
\text { of Relevance }\end{array}$ & $\begin{array}{l}\text { Assessment } \\
\text { of } \\
\text { Coherence }\end{array}$ & $\begin{array}{l}\text { Assessment } \\
\text { of } \\
\text { Adequacy }\end{array}$ & $\begin{array}{l}\text { Overall } \\
\text { CERQual } \\
\text { Assessment } \\
\text { of } \\
\text { Confidence }\end{array}$ & $\begin{array}{l}\text { Explanation of } \\
\text { Judgement }\end{array}$ \\
\hline $\begin{array}{l}\text { Narrative of } \\
\text { Adjustment }\end{array}$ & $\begin{array}{l}\text { Moderate } \\
\text { methodological } \\
\text { limitations (six } \\
\text { studies with } \\
\text { high and four } \\
\text { with moderate } \\
\text { methodological } \\
\text { limitations) }\end{array}$ & $\begin{array}{l}\text { Minor } \\
\text { concerns } \\
\text { about } \\
\text { relevance } \\
\text { (two studies } \\
\text { had other } \\
\text { participants } \\
\text { than EU } \\
\text { citizens, } \\
\text { partial } \\
\text { coverage of } \\
\text { EU } \\
\text { nationalities) }\end{array}$ & $\begin{array}{l}\text { Minor } \\
\text { concerns } \\
\text { about } \\
\text { coherence } \\
\text { (data } \\
\text { reasonably } \\
\text { consistent } \\
\text { within and } \\
\text { across all } \\
\text { studies) }\end{array}$ & $\begin{array}{l}\text { Minor } \\
\text { concerns } \\
\text { about } \\
\text { adequacy } \\
\text { (some } \\
\text { papers } \\
\text { include a } \\
\text { low number } \\
\text { of } \\
\text { participants, } \\
\text { sampling } \\
\text { not always } \\
\text { explained) }\end{array}$ & $\begin{array}{l}\text { Moderate } \\
\text { confidence }\end{array}$ & $\begin{array}{l}\text { The finding was } \\
\text { graded as } \\
\text { moderate because } \\
\text { of moderate } \\
\text { methodological } \\
\text { limitations and } \\
\text { minor concerns } \\
\text { about relevance, } \\
\text { coherence and } \\
\text { adequacy. }\end{array}$ \\
\hline $\begin{array}{l}\text { Employment } \\
\text { realities }\end{array}$ & $\begin{array}{l}\text { Moderate } \\
\text { methodological } \\
\text { limitations (five } \\
\text { studies with } \\
\text { high and three } \\
\text { with moderate } \\
\text { methodological } \\
\text { limitations) }\end{array}$ & $\begin{array}{l}\text { Moderate } \\
\text { concerns } \\
\text { about } \\
\text { relevance } \\
\text { (two studies } \\
\text { had other } \\
\text { participants } \\
\text { than EU } \\
\text { citizens, } \\
\text { partial } \\
\text { coverage of } \\
\text { EU } \\
\text { nationalities, } \\
\text { focus on } \\
\text { specific } \\
\text { employment } \\
\text { types such as } \\
\text { care workers, } \\
\text { bilingual } \\
\text { workers or } \\
\text { professionals) }\end{array}$ & $\begin{array}{l}\text { Minor } \\
\text { concerns } \\
\text { about } \\
\text { coherence } \\
\text { (data } \\
\text { reasonably } \\
\text { consistent } \\
\text { within and } \\
\text { across all } \\
\text { studies) }\end{array}$ & $\begin{array}{l}\text { Minor } \\
\text { concerns } \\
\text { about } \\
\text { adequacy } \\
\text { (some } \\
\text { papers } \\
\text { include a } \\
\text { low number } \\
\text { of } \\
\text { participants, } \\
\text { sampling } \\
\text { not always } \\
\text { explained,) }\end{array}$ & $\begin{array}{l}\text { Low } \\
\text { confidence }\end{array}$ & $\begin{array}{l}\text { The finding was } \\
\text { graded as low } \\
\text { because of } \\
\text { moderate } \\
\text { methodological } \\
\text { limitations, } \\
\text { moderate concerns } \\
\text { about relevance } \\
\text { and minor } \\
\text { concerns about } \\
\text { coherence and } \\
\text { adequacy. }\end{array}$ \\
\hline
\end{tabular}

This review deliberately focused on the pre-Brexit period and thus none of the studies addressed the impact of the 2016 Brexit referendum on EU citizens in the UK. We argue that in 
order to fully understand how Brexit has altered the experience and well-being of EU citizens in the UK, we need to have a clear appreciation of their situation prior to the referendum. This review seeks to provide that historical context. The review is therefore best utilised in conjunction with more recent research in order to provide as complete a picture as possible of EU citizens' well-being and mental health in the UK.

We recommend that further research be conducted addressing the limitations we have identified in the current review. While considerable diversity of experience clearly exists even among members of single EU states, still there is a need for research focusing on nationalities other than Polish (for instance, one might expect the experience of Irish nationals in the UK to differ in important ways). Research that focuses on mental health of EU migrants would be beneficial. This is particularly important in light of the important changes in the acculturative context of the UK as a result of the Brexit referendum in 2016 (Guma and Jones, 2019; Brown at al., 2016). Finally, higher quality studies (for instance, addressing reliability of analysis) would enable greater confidence in the findings.

\section{Conclusions}

While considering the review's limitations and our medium/low confidence in these findings, this review mapped the current state of knowledge on mental health and well-being of EU citizens in the UK. Relatively little is known about their post-migration mental health and well-being, although it is possible that additional studies on EU citizens' employment experiences in the UK may address these issues implicitly. We recommend further high-quality research to address these issues. Future studies should provide new evidence to healthcare professionals and policymakers to see how EU citizens could be supported, and the extent to which support should be tailored according to the country of origin.

This review showed that the acculturation of EU citizens takes time and is not necessarily linear or always successful. Even when one is successfully integrated, a life event could take an individual backwards. The employment, especially around low salaries, poor working conditions, or being overqualified for one's job, had was experienced by EU citizens. The language barrier could worsen these experiences.

\section{References}

Amer, M. M., \& Hovey, J. D. (2007). Socio-demographic Differences in Acculturation and Mental Health for a Sample of 2nd Generation/Early Immigrant Arab Americans. Journal of Immigrant and Minority Health, 9(4), 335. https://doi.org/10.1007/s10903-007-9045-y

Berry, J. W. (2006). Stress perspectives on acculturation. In The Cambridge handbook of acculturation psychology. (pp. 43-57). Cambridge: Cambridge University Press. https://doi.org/10.1017/ CBO9780511489891.007

Berry, J. W., Poortinga, Y. H., Breugelmans, S. M., Chasiotis, A., \& Sam, D. L. (2011). Cross-Cultural Psychology: Research and Applications (3rd ed.). Cambridge: Cambridge University Press. https://doi.org/DOI: 10.1017/CBO9780511974274

Bhugra, D. (2004). Migration and mental health. Acta Psychiatrica Scandinavica, 109(4), 243-258. https://doi.org/10.1046/j.0001-690X.2003.00246.x

Bhugra, D., \& Jones, P. (2001). Migration and mental illness. Advances in Psychiatric Treatment, 7(3), 216222. https://doi.org/10.1192/apt.7.3.216 


\section{The Mental Health and Wellbeing of EU Citizens in the UK}

Bhui, K., Stansfeld, S., McKenzie, K., Karlsen, S., Nazroo, J., \& Weich, S. (2005). Racial/ethnic discrimination and common mental disorders among workers: findings from the EMPIRIC study of ethnic minority groups in the United Kingdom. American Journal of Public Health, 95(3), 496-501. https://doi.org/10.2105/AJPH.2003.033274

Braun, V., \& Clarke, V. (2006). Using thematic analysis in psychology. Qualitative Research in Psychology, 3(2), 77-101. https://doi.org/10.1191/1478088706qp063oa

Brown, D. L., \& Paszkiewicz, I. (2017). The role of food in the Polish migrant adjustment journey. Appetite, 109, 57-65. https://doi.org/10.1016/j.appet.2016.11.024

Brown, R., Zagefka, H., \& Tip, L. K. (2016). “Acculturation in the United Kingdom.” In D. Sam and J. Berry (eds.) The Cambridge Handbook of Acculturation Psychology, Second Edition. Cambridge: Cambridge University Press (pp. 375-395). https://doi.org/10.1017/CBO9781316219218.022

CASP. (2018). An appraisal tool for qualitative research. Retrieved 11 August 2019 from https://caspuk.net/wp-content/uploads/2018/01/CASP-Qualitative-Checklist-2018.pdf

Christensen, K., \& Manthorpe, J. (2016). Personalised risk: new risk encounters facing migrant care workers. Health, Risk \& Society, 18(3/4), 137-152. https://doi.org/10.1080/13698575.2016.1182628

Cieslik, A. (2011). Where Do You Prefer to Work? How the Work Environment Influences Return Migration Decisions from the United Kingdom to Poland. Journal of ethnic and migration studies, 37(9), 1367-1383. https://doi.org/10.1080/1369183x.2011.623613

Close, C., Kouvonen, A., Bosqui, T., Patel, K., O’Reilly, D., \& Donnelly, M. (2016). The mental health and well-being of first generation migrants: a systematic-narrative review of reviews. Globalisation And Health, 12(1), 47-47. https://doi.org/10.1186/s12992-016-0187-3

Cochrane Collaboration. (2019). Cochrane Library.

Condon, L. J., \& McClean, S. (2017). Maintaining pre-school children's health and well-being in the UK: a qualitative study of the views of migrant parents. Journal of Public Health, 39(3), 455-463. https://doi.org/10.1093/pubmed/fdw083

Dhadda, A., \& Greene, G. (2018). 'The Healthy Migrant Effect' for Mental Health in England: Propensityscore Matched Analysis Using the EMPIRIC Survey. Journal of Immigrant and Minority Health, 20(4), 799-808. https://doi.org/10.1007/s10903-017-0570-z

Farr, J., Blenkiron, L., Harris, R., \& Smith, J. A. (2018). “It's My Language, My Culture, and it's Personal!” Migrant Mothers' Experience of Language Use and Identity Change in Their Relationship With Their Children: An Interpretative Phenomenological Analysis [Article]. Journal of Family Issues, 39(11), 30293054. https://doi.org/10.1177/0192513X18764542

Folkman, S., \& Lazarus, R. S. (1988). Coping as a mediator of emotion. Journal of Personality and Social Psychology, 54(3), 466-475. https://doi.org/10.1037/0022-3514.54.3.466

Guma, T., \& Dafydd Jones, R. (2019). "Where are we going to go now?" European Union migrants' experiences of hostility, anxiety, and (non-)belonging during Brexit. Population, Space and Place, 25(1), e2198. https://doi.org/10.1002/psp.2198

Hendriks, M., \& Bartram, D. (2016). Macro-conditions and immigrants' happiness: Is moving to a wealthy country all that matters?. Social Science Research, 56, 90-107. https://doi.org/10.1016/j.ssresearch. 2015.11.006

Hong, J. (2019). Effects of Ethnic Identity on the Relationship Between Mental Health and Perceived Discrimination Among Ethnic Return Migrants: The Case of Korean Chinese Return-Migrated to South Korea. Journal of Immigrant and Minority Health, 21(3), 522-532. https://doi.org/10.1007/s10903-0180775-9

Ibañez, G. E., Dillon, F., Sanchez, M., De La Rosa, M., Li, T., \& Villar, M. E. (2015). Changes in Family Cohesion and Acculturative Stress among Recent Latino Immigrants. Journal of ethnic \& cultural diversity in social work, 24(3), 219-234. https://doi.org/10.1080/15313204.2014.991979

Kirmayer, L. J., Narasiah, L., Munoz, M., Rashid, M., Ryder, A. G., Guzder, J., Hassan, G., Rousseau, C., Pottie, K., Canadian Collaboration for, I., \& Refugee, H. (2011). Common mental health problems in immigrants and refugees: general approach in primary care. CMAJ : Canadian Medical Association 
journal = journal de l'Association medicale canadienne, 183(12), E959-E967. https://doi.org/10.1503 /cmaj.090292

Lee-Treweek, G. (2013). 'Sometimes I just wish I never hear of this term bilingual worker': Difficult clients, emotion work and interpreting with migrants. International Journal of Work Organisation and Emotion, 5(3), 296-315. https://doi.org/10.1504/IJWOE.2013.055907

Lewin, S., Glenton, C., Munthe-Kaas, H., Carlsen, B., Colvin, C. J., Gülmezoglu, M., Noyes, J., Booth, A., Garside, R., \& Rashidian, A. (2015). Using Qualitative Evidence in Decision Making for Health and Social Interventions: An Approach to Assess Confidence in Findings from Qualitative Evidence Syntheses (GRADE-CERQual). PLoS Medicine, 12(10), e1001895. https://doi.org/10.1371/journal.pmed.1001895

Lulle, A., \& King, R. (2016). Ageing well: the time-spaces of possibility for older female Latvian migrants in the UK. Social \& Cultural Geography, 17(3), 444-462. https://doi.org/10.1080/14649365. 2015.1089584

Maciagowska, K. E., \& Hanley, T. (2018). What is known about mental health needs of the post-European Union accession Polish immigrants in the UK? A systematic review. International Journal of Culture \& Mental Health, 11(2), 220-235. https://doi.org/10.1080/17542863.2017.1358755

Moher, D., Liberati, A., Tetzlaff, J., \& Altman, D. G. (2009). Preferred reporting items for systematic reviews and meta-analyses: the PRISMA statement. BMJ, 339, b2535. https://doi.org/10.1136/bmj.b2535

Ndofor-Tah, C., Strang, A., Phillimore, J., Morrice, L., Michael, L., Wood, P., \& Simmons, J. (2019). Home Office Indicators of Integration framework 2019. Retrieved 11 April 2020 from http://sro.sussex.ac.uk/id/eprint/84107/1/_smbhome.uscs.susx.ac.uk_dm50_Desktop_Morrice\%20Hom e\%20Office.pdf

O'Brien, P., \& Tribe, R. (2014). Exploring Polish migrants' adaptation to life in the UK: an interpretative phenomenological analysis. International Journal of Culture \& Mental Health, 7(4), 439-451. https://doi.org/10.1080/17542863.2013.844185

Office for National Statistics. (2019a). Migration Statistics Quarterly Report: August 2019. https://www.ons.gov.uk/peoplepopulationandcommunity/populationandmigration/internationalmigration /bulletins/migrationstatisticsquarterlyreport/august2019\#work-and-study-remain-the-most-commonreasons-to-move-to-the-uk

Office for National Statistics. (2019b). Population of the UK by country of birth and nationality. Retrieved 11 october 2019 from https:/www.ons.gov.uk/peoplepopulationandcommunity/ populationandmigration/ internationalmigration/datasets/populationoftheunitedkingdombycountryofbirthandnationality

Phillimore, J. (2011). Approaches to health provision in the age of super-diversity: accessing the NHS in Britain's most diverse city. Critical Social Policy, 31(1), 5-29. https://doi.org/10.1177/ 0261018310385437

Pumariega, A. J., Rothe, E., \& Pumariega, J. B. (2005). Mental Health of Immigrants and Refugees. Community Mental Health Journal, 41(5), 581-597. https://doi.org/10.1007/s10597-005-6363-1

Sandhu, S., Bjerre, N. V., Dauvrin, M., Dias, S., Gaddini, A., Greacen, T., Ioannidis, E., Kluge, U., Jensen, N. K., Lamkaddem, M., Puigpinós i Riera, R., Kósa, Z., Wihlman, U., Stankunas, M., Straßmayr, C., Wahlbeck, K., Welbel, M., \& Priebe, S. (2013). Experiences with treating immigrants: a qualitative study in mental health services across 16 European countries. Social Psychiatry and Psychiatric Epidemiology, 48(1), 105-116. https://doi.org/10.1007/s00127-012-0528-3

Schmitt, M. T., Branscombe, N. R., Postmes, T., \& Garcia, A. (2014). The Consequences of Perceived Discrimination for Psychological Well-Being: A Meta-Analytic Review. Psychological Bulletin, 140(4), 921-948. https://doi.org/10.1037/a0035754

Schwartz, S. J., Unger, J. B., Zamboanga, B. L., \& Szapocznik, J. (2010). Rethinking the concept of acculturation: implications for theory and research. The American psychologist, 65(4), 237-251. https://doi.org/10.1037/a0019330

Stillman, S., Gibson, J., McKenzie, D., \& Rohorua, H. (2015). Miserable Migrants? Natural Experiment Evidence on International Migration and Objective and Subjective Well-Being. World Development, 65, 79-93. https://doi.org/https://doi.org/10.1016/j.worlddev.2013.07.003 
Stillman, S., McKenzie, D., \& Gibson, J. (2009). Migration and mental health: Evidence from a natural experiment. Journal of Health Economics, 28(3), 677-687. https://doi.org/https://doi.org/10.1016/ j.jhealeco.2009.02.007

Teodorowski, P., Woods, R., Czarnecka, M., \& Kennedy, C. (2019a). How Brexit Impacts EU Citizens' Mental Health and Wellbeing: Research Findings. Retrieved 11 August 2019 from http://www.rgu.ac.uk/brexit-mental-health-research-findings

Teodorowski, P., Woods, R., Czarnecka, M., \& Kennedy, C. (2019b). The mental health and well-being of EU citizens in the UK: a systematic review. Retrieved 5 December 2019 from https:/www.crd.york.ac.uk/ prospero/display_record.php?RecordID $=129203$

Teshome Tesfaye, H., \& Day, J. (2015). Health visitors' perceptions of barriers to health and well-being in European migrant families. Community Practitioner, 88(1), 22-25.

Wallace, S., Nazroo, J., \& Bécares, L. (2016). Cumulative Effect of Racial Discrimination on the Mental Health of Ethnic Minorities in the United Kingdom. American Journal of Public Health, 106(7), 12941300. https://doi.org/10.2105/AJPH.2016.303121

Weishaar, H. B. (2008). Consequences of international migration: A qualitative study on stress among Polish migrant workers in Scotland. Public Health, 122(11), 1250-1256. https://doi.org/10.1016/ j.puhe.2008.03.016

Weishaar, H. B. (2010). "You have to be flexible"-Coping among polish migrant workers in Scotland. Health \& Place, 16(5), 820-827. https://doi.org/10.1016/j.healthplace.2010.04.007

Whittemore, R., \& Knafl, K. (2005). The integrative review: updated methodology. Journal of Advanced Nursing, 52(5), 546-553. https://doi.org/10.1111/j.1365-2648.2005.03621.x

Wiking, E., Johansson, S.-E., \& Sundquist, J. (2004). Ethnicity, acculturation, and self reported health. A population based study among immigrants from Poland, Turkey, and Iran in Sweden. Journal of Epidemiology and Community Health, 58(7), 574. https://doi.org/10.1136/jech.2003.011387

World Health Organisation. (2014). Mental health: a state of well-being. Retrieved 19 August 2019 from https://www.who.int/features/factfiles/mental_health/en/. 